\title{
The Relationship Between Corporate Social Responsibility Reporting and Corporate Governance: Evidence from Turkish Banking Sector
}

\author{
Nalan Akdoğan, Ozan Gülhan, Melike Aktaş \\ Başkent University, Ankara, Turkey
}

\begin{abstract}
Corporate social responsibility (CSR) reporting and corporate governance concepts have been two important concepts for researchers and corporate managers in recent years. The purpose of this study is to analyze the potential effect of corporate governance levels of Turkish deposit banks' on CSR reporting. First, the concentration areas of CSR reporting of Turkish deposit banks were identified between the years 2012-2014 from their annual and sustainability reports. Second, the concentration areas were divided into subgroups and each bank was rated according to their disclosure level. Finally, a model was designed in order to determine the relationship between CSR reporting and corporate governance. In the model, CSR reporting rating scores are used as a dependent variable, and financial data and corporate governance indicators of banks are used as independent variables. Model results indicate that corporate governance level and bank's size have a significant effect on the level of CSR reporting in Turkish banking sector.
\end{abstract}

Keywords: corporate social responsibility, corporate governance, banking

\section{Introduction}

Corporate social responsibility (CSR) reporting and corporate governance concepts have been two important issues for academicians and corporate managers in recent years. CSR reporting on a regular basis not only improves the value of the company but also shows the contribution of the company to the society that it operates. Likewise increasing level of corporate governance has positive effects on employee loyalty, corporate reputation, and investor interest.

Recent financial turmoil showed once again that banks are the most important institutions in global economy. With their intermediary function, banks have an important impact on society. Today, sustainable and responsible investing has been attracting more attention in global banking industry. According to the Forum for Sustainable and Responsible Investment's 2014 report (US SIF, 2014), every 1 of 6 dollars of investment is sustainable, responsible investment in the US. Especially in crises time, banks' reputation has been damaged drastically. From banks' view, CSR reporting is a useful tool to restore reputation and for the global economy, improving corporate governance level is important to prevent crises.

Nalan Akdoğan, Professor, Faculty of Commercial Sciences, Başkent University.

Ozan Gülhan, Ph.D. candidate, Department of Acconting and Finance, Başkent University.

Melike Aktaş, Ph.D. candidate, Department of Acconting and Finance, Başkent University. 
Turkish financial system is more bank-oriented compared to most western countries, which is the reason why banking sector has vital importance and dominates the financial sector. Since more than $90 \%$ of the financial sector assets have been managed by banks, governance structure of these institutions and their contribution to the society where they operate is important. The main governmental bodies that regulate the corporate governance in Turkey are the Capital Markets Board (CMB) and the Banking Regulation and Supervision Agency (BRSA) of Turkey. These two bodies encourage the improvement of corporate governance structures of listed firms and banks with the regulations which are in line with international standards. CSR reporting has been gaining importance since the last decade in Turkey. With the constitution of Borsa İstanbul (BIST) Sustainability Index in 2014, today, all BIST-50 listed firms and BIST-100 listed firms which are volunteers are listed in this index.

Earlier studies about determinants of CSR reporting concentrate on several issues like disclosed information type, relation between company performance, firm size, country origin, industry type, social history, stakeholder pressure and CSR (Fifka, 2013). Even though most of the studies about CSR reporting and corporate governance have been done in context of developed countries, recently, there has been a remarkable interest in developing countries about the subject.

Even though there are some studies like Ertuna and Tükel (2009), İliç (2010), Kavut (2010), Arsoy, Arabacı, and Çiftçioğlu (2012), and Başar (2014) about CSR in Turkey, to the knowledge of the authors, there is no specific study about CSR reporting and corporate governance relation in banking. This study is different from previous works on CSR reporting in Turkey. First, this study rates Turkish banks' CSR reporting level and second, it evaluates the relation between CSR reporting and corporate governance level including financial and non-financial data.

This paper is structured as follows: the next section explains the research purpose and hypotheses, the third section gives information about data and methodology, the fourth section discusses the research findings, and the last section concludes.

\section{Research Purpose and Hypotheses}

This paper has three main objectives. First, the CSR reporting level and CSR reporting areas of Turkish banks are identified between the years of 2012-2014 from their annual and sustainability reports. Second, CSR reporting areas are separated into subgroups and banks in sample were rated according to their disclosure level. Finally, to evaluate the relation between corporate governance and CSR, a model was designed with financial and corporate governance variables.

Most of the CSR studies assert legitimacy theory and stakeholder theory as the main motive for CSR reporting. Besides these theories, agency theory is also another important view to explain CSR. Content analysis is a widely-used technique to codify and group qualitative information into quantitative information. The main approach about content analysis is to codify the text according to chosen criteria (Weber, 1990). However, the main drawback is that this approach focuses more on quantity rather than quality (Guthrie \& Abeysekera, 2006). Guthrie and Mathews (1985) and Guthrie, Petty, Yongvanich, and Ricceri (2004) asserted that a content analysis should meet three criteria to be effective. First, the categories-unit of analysis should be defined clearly. Second, data capture must be systematic. Finally, analysis must be reliable and valid. 
As stated above, codifying and grouping the information from banks' annual and sustainability reports was done in line with previous studies (Khan, 2010; Gray, Kouhy, \& Lavers, 1995a; 1995b; Gray, 2002; Guthrie \& Parker, 1989; Guthrie \& Abeysekera, 2006) and the local industry features. The annual report of the companies is a foremost source of data to analyze voluntary reporting for social and environmental studies (Gibson \& Guthrie, 1994).

In line with the literature, the concentration areas of CSR reporting of Turkish deposit banks were identified between the years 2012-2014 from their annual and sustainability reports. CSR reporting is identified as customers, employees, society, ecosystem and other issues (see Annex A). CSR reporting areas were divided into four subgroups according to literature about the subject (see Annex A). Each subgroup has three different variables (see Annex B) and each bank is rated according to their disclosure level.

As a result, to identify the CSR reporting areas of Turkish banks, five main areas were determined including four subgroups. For each subgroup, three different variables are identified to rate each bank. Only the other issues group has two variables. As a result, 50 different variables were selected, if bank discloses the variable it gets the value of " 1 " and " 0 " if otherwise. As a result, each bank has a rating for the specific year. These ratings are used as a dependent variable for the model. To avoid errors in rating process, all three authors were involved in coding process.

Previous studies like Dahya, Lonie, and Power (1996), Carter, Simkins, and Simpson (2003), Branco and Rodrigues (2008), and Khan (2010) showed the positive relation between CSR reporting and corporate governance. According to Fama and Jensen (1983), increasing number of non-executive members on the board is a useful tool to solve the conflicts between managers and owners. In the context of this idea, non-executive members encourage higher level of CSR reporting to protect owners and shareholders' rights. In the light of these studies, the first hypothesis is as follows:

$\mathrm{H}_{1}$ : There is a positive relation between higher proportion of non-executive directors on the board and the level of CSR reporting.

Branco and Rodrigues (2008), Carter et al. (2003), and Ibrahim and Angelidis (1994) asserted that higher board diversity is related with higher CSR reporting. In the light of these studies, the second hypothesis is:

$\mathrm{H}_{2}$ : There is a positive relation between higher proportion of women directors on the board and the level of CSR reporting.

Bank ownership structure is another issue about CSR reporting level. Even though studies like Ayuso and Argandoña (2009), Fields and Keys (2003), and Oh, Chang, and Martynov (2011) showed the positive contribution of foreign director existence on board to CSR reporting. Based on the literature, the third hypothesis is as follows:

$\mathrm{H}_{3}$ : There is a positive relation between higher proportion of foreign directors on the board and the level of CSR reporting.

Some banks announce their level of compliance to corporate governance principles with Corporate Governance Principles Compliance Reports on a regular basis. Generally, banks which have better corporate governance structures issue these reports. According to discussions above, the fourth hypothesis is as follows:

$\mathrm{H}_{4}$ : There is a positive relation between publishing Corporate Governance Principles Compliance Report issuance and the level of CSR reporting. 
There are numerous studies which explained the relation between CSR level and financial performance/indicators (including firm size). The main idea of these studies is that large firms give more importance to society where they operate (Trotman \& Bradley, 1981; Andrew, Gul, Guthrie, \& Teoh, 1989; Cowen, Ferreri, \& Parker, 1987; Patten, 1991; Roberts, 1992; Muller \& Kolk, 2010; Suzuki, Tanimoto, \& Kokko, 2010; Hernaus \& Stojanovic, 2015). Moreover, highly profitable and leveraged firms feel free to contribution to CSR and increase their reputation. On the other hand, many studies found positive (Ruf, Muralidhar, Brown, Janney, \& Paul, 2001; Vitezic, 2011; Waddock \& Graves, 1997) or negative (Jaggi \& Freedman, 1992; Jones, Van der Laan, Frost, \& Loftus, 2008; Makni, Francoeur, \& Bellavance, 2009) relation between profitability and CSR level. Based on the discussion above, the fifth, sixth, and seventh hypotheses are given below:

$\mathrm{H}_{5}$ : There is a positive relation between bank size and the level of CSR reporting.

$\mathrm{H}_{6}$ : There is a positive relation between leverage level and the level of CSR reporting.

$\mathrm{H}_{7}$ : There is a significant relation between profitability and the level of CSR reporting.

Based on the hypotheses, a model was designed in order to determine the relationship between CSR reporting and corporate governance as follows:

$$
C S R L V L=\beta_{0}+\beta_{1} I N D B M+\beta_{2} W B M+\beta_{3} F B M+\beta_{4} S I Z E+\beta_{5} R O E+\beta_{6} L E V L+\beta_{7} C G P C P+e_{t}
$$

In the model, CSR reporting rating scores were used as a dependent variable, financial data and corporate governance components of banks were used as independent variables. The variables used in the model and their calculation are given in Table 1.

Table 1

Variables, Calculation Method, and Expected Relations

\begin{tabular}{|l|l|l|l|}
\hline Variable & Variable type & Explanation & Calculation \\
\hline CSRLVL & Dependent & $\begin{array}{l}\text { Corporate social responsibility level-index } \\
\text { calculated according to CSR information } \\
\text { disclosed by banks in annual reports }\end{array}$ & Disclosed information/total specified information \\
\hline$I N D B M$ & Independent & Percentage of independent board members & Independent board members/total board members 100 \\
\hline$W B M$ & Independent & Percentage of women board members & Women board members/total board members ${ }^{*} 100$ \\
\hline$F B M$ & Independent & Percentage of foreign board members & Foreign board members/total board members ${ }^{*} 100$ \\
\hline$S I Z E$ & Independent & Asset size of each bank & Bank asset/total assets ${ }^{*} 100$ \\
\hline$R O E$ & Independent & Return on equity & Net profit/total equity ${ }^{*} 100$ \\
\hline$L E V L$ & Independent & Leverage level & Total debt/total equity ${ }^{*} 100$ \\
\hline$C G P C P$ & Independent & $\begin{array}{l}\text { Corporate Governance Principles Compliance } \\
\text { Report }\end{array}$ & $\begin{array}{l}\text { if the bank discloses Corporate Governance } \\
\text { Principles Compliance Report, and 0 if otherwise }\end{array}$ \\
\hline
\end{tabular}

\section{Methodology and Data}

The data used for the research include 23 deposit banks which constitute more than $90 \%$ of total assets of Turkish banking sector. Annual and sustainability reports were collected from banks' websites and used for analyzing the CSR reporting level. Financial data were gathered from the Turkish Bankers Association's and Banking Regulation and Supervision Agency's databases which are open to public.

Panel data comprise of cross-sectional units observed at different points in time. The combination of cross-sectional and time series data allows for richer econometric model specifications and more accurate conclusions (Gujarati \& Porter, 1999). The fundamental advantage of a panel data set over a cross section is that it allows flexibility in modelling differences in behavior across individuals. 
The basic framework is a regression model of the form:

$$
\begin{gathered}
y_{i t}=\beta_{1 i t}+\beta_{2 i t} X_{2 i t}+\ldots \beta_{k i t} X_{k i t}+e_{i t} \quad i=1,2, \ldots, N ; t=1,2, \ldots, T \\
E\left(e_{i t}\right)=0 \text { ve } \operatorname{Var}\left(e_{i t}\right)=\sigma_{\varepsilon}^{2}
\end{gathered}
$$

Panel data can be balanced when all individuals are observed in all time periods or unbalanced when individuals are not observed in all time periods. The data used in the paper are balanced panel.

Random effect model and fixed effect model are two common approaches to analyze panel data. Random effect model utilizes both within and between group variations but requires that the error term is not correlated with other independent variables. In contrast, the validity of fixed effect model does not rely on such a requirement. The drawback is that it only utilizes within group variation. Hausman test is used to see if the error term is not correlated with other independent variables.

The specification test devised by Hausman (1978) is used to test for orthogonality of the random effects and the regressors. The test is based on the idea that under the hypothesis of no correlation, both OLS (Ordinary Least Squares) in the LSDV (Least Squares Dummy Variable) model and GLS (Generalized Least Squares) are consistent, but OLS is inefficient (Baltagi, 1995), whereas under the alternative, OLS is consistent, while GLS is not. Therefore, under the null hypothesis, the two estimates should not differ systematically, and a test can be based on the difference.

The original form of the Hausman statistic can be computed as follows. Let $\delta_{R E}$ denote the vector of random effects estimates without the coefficients on time - constant variables or aggregate time variables, and let $\delta_{F E}$ denote the corresponding fixed effects estimates; let these each be $M \times 1$ vectors. Then, it is distributed asymptotically as $\chi^{2}{ }_{M}$. If the test statistic is greater than the critical value, the hypothesis can be rejected that the coefficients between the two models are the same. In this case, the fixed effects model is much more preferable than the random effect:

$$
H=\left(\delta_{F E}-\delta_{R E}\right)^{\prime}\left[A v \hat{a} r\left(\delta_{F E}\right)-A v \hat{a r}\left(\delta_{R E}\right)\right]^{-1}\left(\delta_{F E}-\delta_{R E}\right)
$$

\section{Research Findings}

The purpose of this section is to present and discuss the main results of the study. Table 2 presents the CSR reporting areas of Turkish deposit banks. The scope of disclosed items is wide and the most disclosed groups between years 2012 and 2014 are employees, followed by products. On the other hand, when the increase level is examined, disclosures about ecosystem increased by $55.9 \%$ in three years. Results showed that in that period, Turkish banks have begun to give more importance to environmental issues in CSR reporting.

Figure 1 provides the CSR reporting ratings of Turkish deposit banks between the years 2012-2014. As seen in the figure, average and asset weighted average ratings of the banking sector increased in the period. Moreover, higher asset weighted ratings indicate the size effect to the CSR reporting which shows that bank size has a positive relation with CSR reporting. 
Table 2

CSR Reporting Areas

\begin{tabular}{|c|c|c|c|c|c|}
\hline & & 2012 & 2013 & 2014 & $\begin{array}{l}\text { Change } \\
\text { 2012-2014 (\%) }\end{array}$ \\
\hline \multirow{4}{*}{ Customers } & Products & 18 & 23 & 30 & 66.7 \\
\hline & Customer satisfaction & 28 & 28 & 35 & 25.0 \\
\hline & Customer education & 27 & 29 & 32 & 18.5 \\
\hline & Other issues related to customers & 25 & 28 & 27 & 8.0 \\
\hline & Total & 98 & 108 & 124 & 26.5 \\
\hline \multirow[t]{5}{*}{ Employees } & Employee benefits & 54 & 57 & 62 & 14.8 \\
\hline & Employee structure & 34 & 41 & 41 & 20.6 \\
\hline & Employees' training & 46 & 49 & 50 & 8.7 \\
\hline & Other issues related to employees & 24 & 37 & 38 & 58.3 \\
\hline & Total & 158 & 184 & 191 & 20.9 \\
\hline \multirow[t]{5}{*}{ Society } & Women & 15 & 22 & 19 & 26.7 \\
\hline & Contribution to SMEs & 35 & 41 & 37 & 5.7 \\
\hline & Contribution to health/education/culture & 18 & 16 & 20 & 11.1 \\
\hline & Other issues related to society & 26 & 35 & 35 & 34.6 \\
\hline & Total & 94 & 114 & 111 & 11.8 \\
\hline \multirow[t]{5}{*}{ Ecosystem } & Energy & 22 & 28 & 31 & 40.9 \\
\hline & Corporate pollution & 18 & 29 & 33 & 83.3 \\
\hline & Climate change & 13 & 19 & 18 & 38.5 \\
\hline & Other issues related to ecosystem & 15 & 23 & 24 & 60.0 \\
\hline & Total & 68 & 99 & 106 & 55.9 \\
\hline Other & & 4 & 4 & 4 & 0.0 \\
\hline
\end{tabular}

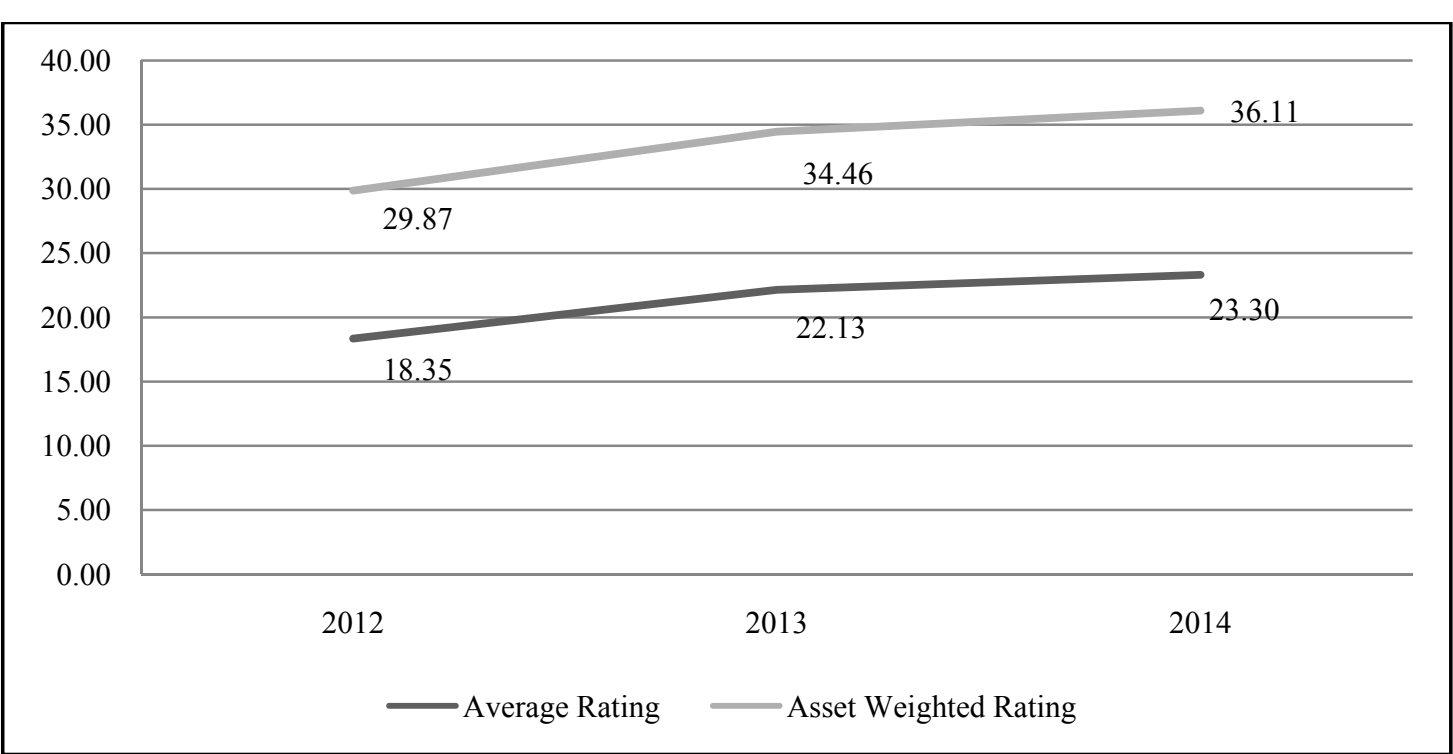

Figure 1. CSR reporting ratings of Turkish banking sector in years of 2012-2014.

Figure 2 shows the CSR reporting ratings of individual banks between years 2012 and 2014. In that period, while 18 banks' ratings have increased, five of them have decreased and two remained the same. 


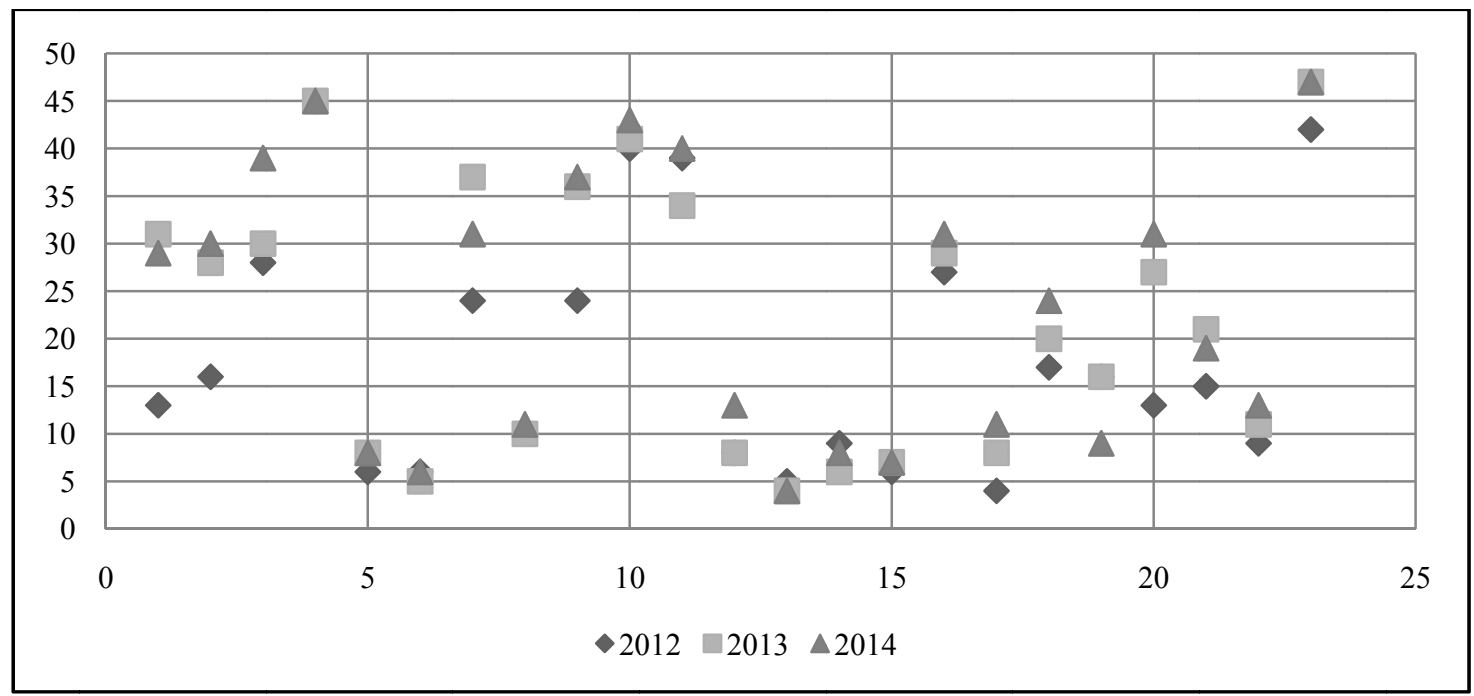

Figure 2. CSR reporting ratings of individual banks in years of 2012-2014.

Figure 3 provides CSR reporting ratings of bank groups between the years 2012 and 2014. In 2012, privately-owned deposit banks have the highest average ratings followed by state-owned deposit banks and foreign banks founded in Turkey. In 2013, state-owned deposit banks have been the leader of the bank groups. This finding shows that the ownership structure is also another vital element of CSR reporting in Turkey.

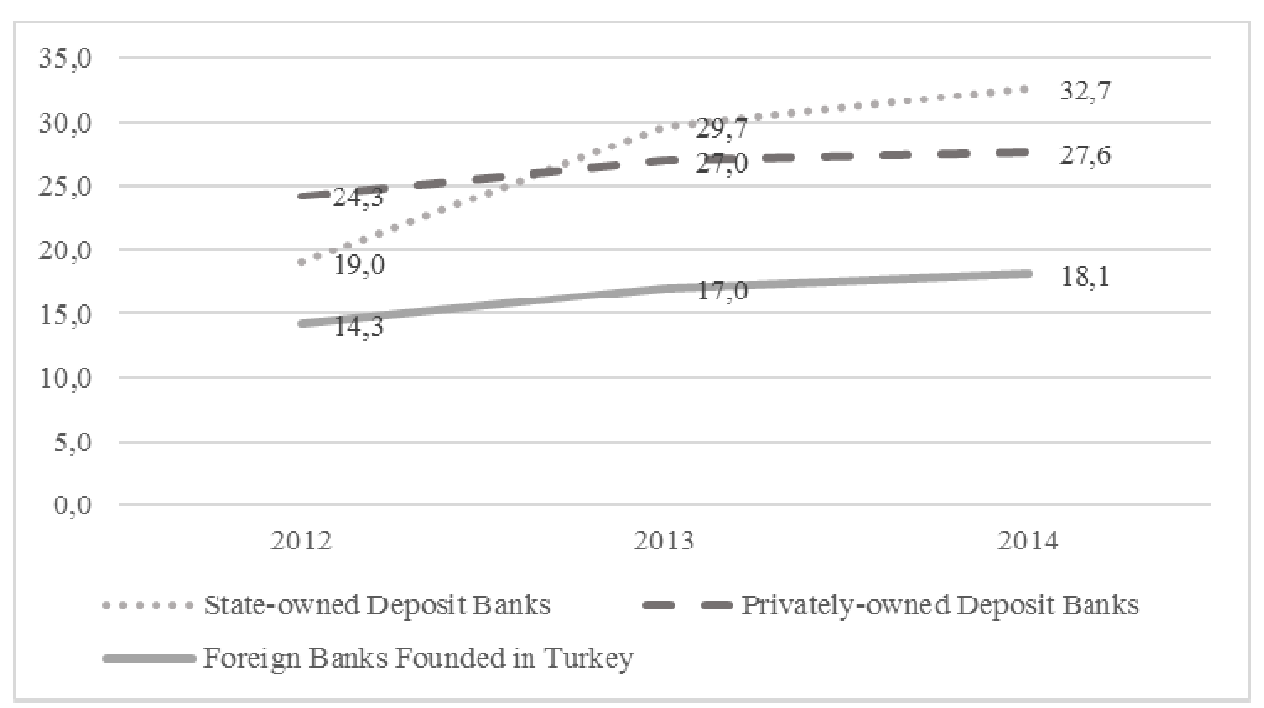

Figure 3. CSR reporting ratings of bank groups.

Table 3 provides descriptive statistics for the deposit banks between the years 2012 and 2014. In this study, the structure of board of directors is analyzed in three categories which are independent members, women members, and foreign members. The mean value of foreign representation is $50 \%$ with a highest percentage of foreign representation on the bank board is over $88 \%$. Statistically, the most significant component of board of directors is foreigners. The average level of women representation on the board of directors is about $8 \%$ and the ratio of independent members is approximately $28 \%$. Asset size, profit, and leverage are included in the study as bank fundamental variables. Overall, return on equity has the highest mean value of $9.51 \%$. Asset size (4\%) and leverage $(8 \%)$ have relatively small proportions of the variables. 
Table 3

Descriptive Statistics

\begin{tabular}{lcccrrrrl}
\hline & CSRLVL & INDBM & WBM & \multicolumn{1}{c}{ FBM } & \multicolumn{1}{c}{ SIZE } & \multicolumn{1}{c}{ ROE } & \multicolumn{1}{c}{ LEVL } & $C G P C P$ \\
\hline Min. & 4.00 & 18.18 & 0.000 & 0.00 & 0.070 & -10.290 & 1.519 & 0.0000 \\
1st Qu. & 8.00 & 22.22 & 0.000 & 0.00 & 0.430 & 5.930 & 6.255 & 0.0000 \\
Median & 17.00 & 28.57 & 7.140 & 50.00 & 2.020 & 11.350 & 7.676 & 0.0000 \\
Mean & 21.26 & 28.32 & 7.939 & 38.15 & 4.348 & 9.506 & 8.043 & 0.4928 \\
3rd Qu. & 31.00 & 33.33 & 11.110 & 55.56 & 8.780 & 13.340 & 9.192 & 1.0000 \\
Max. & 47.00 & 55.56 & 28.570 & 88.89 & 14.210 & 21.060 & 18.171 & 1.0000 \\
\hline
\end{tabular}

The expected signs for the dependent variables are presented in Table 4.

Table 4

Expected Signs of Dependent Variables in the Panel Data Models

\begin{tabular}{|l|l|}
\hline Dependent variables & Expected sign \\
\hline$I N D B M$ & + \\
\hline$W B M$ & + \\
\hline$F B M$ & + \\
\hline$S I Z E$ & + - \\
\hline$R O E$ & + \\
\hline$L E V L$ & + \\
\hline$C G P C P$ & + \\
\hline
\end{tabular}

Table 5 presents the results of the panel data estimations (both the fixed effect and the random effect models) of the determinants of the CSR level for the Turkish banking sector.

The estimators are provided for both fixed and random effect models together with the associated Hausman statistics, which are used to diagnose which model is more appropriate for the dataset. The statistics of the Hausman test indicate that the interpretations on the variables should be based on the random-effect models, which are the preferred specification. From Table 6, the random-effect model needs to be used as it has consistent estimates ( $p$-value $0.217>0.05$ ).

Table 5

Determinants of CSR Level of the Deposit Banks

\begin{tabular}{|c|c|c|c|c|}
\hline \multicolumn{5}{|c|}{ Fixed effects model } \\
\hline & Estimate & Std. error & $t$-value & $\operatorname{Pr}(>|t|)$ \\
\hline$I N D B M$ & 0.083292 & 0.101919 & 0.8172 & 0.4190270 \\
\hline$W B M$ & 0.181229 & 0.218300 & 0.8302 & 0.4117609 \\
\hline$F B M$ & -0.009464 & 0.091579 & -0.1033 & 0.9182496 \\
\hline SIZE & 8.183904 & 2.625207 & 3.1174 & $0.0035212^{* *}$ \\
\hline$R O E$ & -0.053520 & 0.171607 & -0.3119 & 0.7568854 \\
\hline$L E V L$ & -0.750641 & 0.385952 & -1.9449 & 0.0594163 \\
\hline$C G P C P$ & 7.694345 & 3.396034 & 2.2657 & $0.0294131^{*}$ \\
\hline Factor (Year) 2013 & 4.110895 & 1.418647 & 2.8978 & $0.0062815^{* *}$ \\
\hline Factor (Year) 2014 & 5.212221 & 1.336820 & 3.8990 & $0.0003921^{* * *}$ \\
\hline Total sum of squares & 931.33 & & & \\
\hline Residual sum of squares & 458.89 & & & \\
\hline$R$-squared & 0.50728 & & & \\
\hline Adj. $R$-squared & 0.27202 & & & \\
\hline$F$-statistic & 4.23258 or & DF, $p$-valu & & \\
\hline
\end{tabular}


(Table 5 continued)

\begin{tabular}{|c|c|c|c|c|}
\hline \multicolumn{5}{|c|}{ Random effects model } \\
\hline & Estimate & Std. error & $t$-value & $\operatorname{Pr}(>|t|)$ \\
\hline (Intercept) & 3.782068 & 4.530968 & 0.8347 & 0.4072454 \\
\hline$I N D B M$ & 0.060950 & 0.088211 & 0.6910 & 0.4923025 \\
\hline$W B M$ & 0.169634 & 0.119110 & 1.4242 & 0.1596597 \\
\hline$F B M$ & 0.069253 & 0.043190 & 1.6034 & 0.1141785 \\
\hline SIZE & 2.125024 & 0.291689 & 7.2852 & $8.893 \mathrm{e}-10^{* * *}$ \\
\hline$R O E$ & -0.180982 & 0.145607 & -1.2430 & 0.2188018 \\
\hline$L E V L$ & -0.296199 & 0.294893 & -1.0044 & 0.3192733 \\
\hline$C G P C P$ & 8.723043 & 2.220289 & 3.9288 & $0.0002265^{* * *}$ \\
\hline Factor (Year) 2013 & 2.821053 & 1.288243 & 2.1898 & $0.0325016^{*}$ \\
\hline Factor (Year) 2014 & 4.168301 & 1.242287 & 3.3553 & $0.0013906^{* *}$ \\
\hline Total sum of squares & $2,590.7$ & & & \\
\hline Residual sum of squares & 780.54 & & & \\
\hline$R$-squared & 0.69872 & & & \\
\hline Adj. $R$-squared & 0.59745 & & & \\
\hline$F$-statistic & 15.2032 on & $\mathrm{DF}, p$-value & & \\
\hline
\end{tabular}

Note. $^{*, * *}$, and ${ }^{* * \%}$ : Statistical significance at $10 \%, 5 \%$, and $1 \%$, respectively.

Table 6

Hausman Test

Hausman test

Data: $C S R L V L \sim I N D B M+W B M+F B M+A S S I Z E+R O E+L E V L+C G I+C G P C P+\ldots$

chisq $=12.648, \mathrm{df}=9, p$-value $=0.1792$

Alternative hypothesis: one model is inconsistent

Hausman test (choose random effects)

According to the results of random effects model, the variables of the structure of board of directors exhibit an expected positive sign with respect to CSR level. However, none of the variables are statistically significant. Although the empirical literature considers higher ratios of independent, female, and foreign members to be an indicator of higher CSR level, finding strong evidence has failed in favor of this proposition across the deposit banks in Turkey. The variable of bank fundamentals is significant in one out of three specifications. The significant and positive sign on the variable "asset size" implies the fact that bank size is an important factor that affects CSR reporting level. The coefficient of $L E V L$ has a negative sign which is inconsistent with the expected sign and it is not significant in the model. Additionally, CSR level seems to be positively related with the disclosure of Corporate Governance Principles Compliance Report and is also significant. Sixty percent of dependent variables describe the changes in CSR level (Adjusted $R$-squared $=60 \%)$.

A correlation matrix is presented in Table 7. CSR level is significantly positively correlated to asset size which is interpreted as reflecting the fact that high level of CSR increases the level of asset. The level of CSR is positively associated with correlation coefficient of $0.71(p<0)$ proportion of the disclosure of Corporate Governance Principles Compliance Report and there is a positive correlation between CSR level and ROE. 
Table 7

Correlation Matrix Between Variables

\begin{tabular}{lllllllll}
\hline Variable & CSRLVL & INDBM & WBM & FBM & SIZE & ROE & LEVL & CGPCP \\
\hline CSRLVL & 1 & & & & & & & \\
INDBM & 0.21 & 1 & & & & & & \\
$W B M$ & 0.22 & -0.23 & 1 & & & & & \\
$F B M$ & -0.22 & 0.04 & -0.01 & 1 & & & & \\
$S I Z E$ & $0.8^{* * *}$ & 0.05 & 0.01 & $-0.48^{* * *}$ & 1 & & & \\
$R O E$ & $0.3^{*}$ & 0.07 & 0.04 & $-0.5^{* * *}$ & $0.49^{* * *}$ & 1 & & \\
$L E V L$ & 0.08 & 0.12 & 0.06 & -0.02 & 0 & -0.15 & 1 & \\
$C G P C P$ & $0.71^{* * *}$ & $0.32^{*}$ & 0.22 & -0.19 & $0.48^{* * *}$ & $0.43^{* *}$ & 0.22 & 1 \\
\hline Note. ${ }^{* * *}$, and ${ }^{* * *}:$ Statistical significance at $10 \%, 5 \%$, and $1 \%$, respectively. & & &
\end{tabular}

\section{Conclusion}

This study examines the CSR reporting of Turkish deposit banks from their annual and sustainability reports between 2012 and 2014 with content analysis. Moreover, it also put forth the relation between CSR reporting and corporate governance.

The results show that the scope of CSR reporting is extensive in Turkish banking sector. Moreover, the most disclosed items by Turkish deposit banks are about employees; however, in recent years, disclosed items about environment are increasing noticeably. Additionally, between the years 2012 and 2014, Turkish deposit banks increased the information disclosed about CSR among all categories and total increase is $26.5 \%$. According to the CSR reporting ratings, asset weighted ratings of sector are higher than average ratings in time which points out size of bank is important in CSR reporting. State-owned deposit banks have increased their rating in three years and they have the highest CSR reporting level in 2014. This figure shows that the ownership structure is also another important element of CSR engagement. When the individual banks' ratings are examined, 78\% of the banks increased their ratings between the years 2012-2014.

In order to achieve second purpose of the research, a regression is used to determine the relation between CSR reporting and corporate governance and financial fundamentals of banks. As corporate governance variables, board structure (independent, women and foreign member proportions) and issuance of corporate governance compliance report are used. Leverage level, ROE, and asset size variables are used as financial variables. The regression result showed expected signs of variables which are consistent with literature other than leverage level. However, only size and issuance of corporate governance compliance report are statistically significant. As a result, the size of a bank and issuance of corporate governance compliance report matters in Turkey about higher CSR reporting.

Even though this study has some practical implications, it has some limitations. First, this study uses content analysis which is very prone to human error and variables that represent the CSR reporting level might be subjective. Second, in order to determine the CSR reporting levels of banks, only annual and sustainability reports are used in this study. Further studies can use more sources like social and mass media to get more insight about the CSR levels of banks. Third, in Turkey, CSR history in banking is not too long compared to western countries, so it is not easy to lengthen the time frame to provide new insights. This issue limits the dataset of the study. However, in couple years, studies with different variables and extensive data will bring better perception to CSR reporting in Turkish banking sector. 


\section{References}

Andrew, B. H., Gul, F. A., Guthrie, J. E., \& Teoh, H. Y. (1989). A note on corporate social disclosure practices in developing countries: The case of Malaysia and Singapore. The British Accounting Review, 21(4), 371-376.

Arsoy, A. P., Arabacı, Ö., \& Çiftçioğlu, A. (2012). Corporate social responsibility and financial performance relationship: The case of Turkey. The Journal of Accounting and Finance, 53, 159-176.

Ayuso, S., \& Argandoña, A. (2009). Responsible corporate governance: Towards a stakeholder board of directors? Working Paper No. 701, IESE Business School, Barcelona.

Baltagi, B. H. (1995). Economic analysis of panel data. John Wiley \& Sons, Ltd..

Başar, B. (2014). Kurumsal Sosyal Sorumluluk Raporlaması ve Finansal Performans Arasındaki İlişki: Borsa İstanbul'da İşlem Gören Kimya-Petrol-Plastik Sektörü Şirketleri Üzerine Bir Araştırma. Yönetim ve Ekonomi: Celal Bayar Üniversitesi İktisadi ve İdari Bilimler Fakültesi Dergisi, 21(2).

Branco, M. C., \& Rodrigues, L. L. (2008). Social responsibility disclosure: A study of proxies for the public visibility of Portuguese banks. The British Accounting Review, 40(2), 161-181.

Carter, D. A., Simkins, B. J., \& Simpson, W. G. (2003). Corporate governance, board diversity, and firm value. Financial Review, $38(1), 33-53$.

Cowen, S. S., Ferreri, L. B., \& Parker, L. D. (1987). The impact of corporate characteristics on social responsibility disclosure: A typology and frequency-based analysis. Accounting, Organizations and Society, 12(2), 111-122.

Dahya, J., Lonie, A. A., \& Power, D. M. (1996). The case for separating the roles of chairman and CEO: An analysis of stock market and accounting data. Corporate Governance: An International Review, 4(2), 71-77.

Ertuna, B., \& Tükel, A. (2009). Türkiye'de KSS Uygulamaları: Geleneksel ve Küresel Arasında. Journal of Management Research/Yönetim Araştırmaları Dergisi, 9(2), 145-172.

Fama, E. F., \& Jensen, M. C. (1983). Separation of ownership and control. The Journal of Law \& Economics, 26(2), 301-325.

Fields, M. A., \& Keys, P. Y. (2003). The emergence of corporate governance from Wall St. to Main St.: Outside directors, board diversity, earnings management, and managerial incentives to bear risk. Financial Review, 38(1), 1-24.

Fifka, M. S. (2013). Corporate responsibility reporting and its determinants in comparative perspective - A review of the empirical literature and a meta-analysis. Business Strategy and the Environment, 22(1), 1-35.

Gibson, R., \& Guthrie, J. (1994). The greening of public sector annual reports: Towards a benchmark. Public Sector Centre of Excellence. Readings in Accounting Developments in the Public Sector, 95, 68-79.

Gray, R. (2002). The social accounting project and accounting organizations and society privileging engagement, imaginings, new accountings and pragmatism over critique? Accounting, Organizations and Society, 27(7), 687-708.

Gray, R., Kouhy, R., \& Lavers, S. (1995a). Corporate social and environmental reporting: A review of the literature and a longitudinal study of UK disclosure. Accounting, Auditing \& Accountability Journal, 8(2), 47-77.

Gray, R., Kouhy, R., \& Lavers, S. (1995b). Constructing a research database of social and environmental reporting by UK companies. Accounting, Auditing \& Accountability Journal, 8(2), 78-101.

Gujarati, D. N., \& Porter, D. C. (1999). Essentials of econometrics. McGraw Hill.

Guthrie, J., \& Abeysekera, I. (2006). Content analysis of social, environmental reporting: What is new? Journal of Human Resource Costing \& Accounting, 10(2), 114-126.

Guthrie, J., \& Mathews, M. R. (1985). Corporate social accounting in Australasia. Research in Corporate Social Performance and Policy, 7(1), 251-277.

Guthrie, J., \& Parker, L. D. (1989). Corporate social reporting: A rebuttal of legitimacy theory. Accounting and Business Research, 19(76), 343-352.

Guthrie, J., Petty, R., Yongvanich, K., \& Ricceri, F. (2004). Using content analysis as a research method to inquire into intellectual capital reporting. Journal of Intellectual Capital, 5(2), 282-293.

Hausman, J. A. (1978). Specification tests in econometrics. Econometrica, 46(6), 1251-1271.

Hernaus, A. I., \& Stojanovic, A. (2015). Determinants of bank social responsibility: Case of Croatia. E+M Ekonomie a Management, 2, 117-134.

Ibrahim, N. A., \& Angelidis, J. P. (1994). Effect of board members' gender on corporate social responsiveness orientation. Journal of Applied Business Research, 10(1), 35-40.

İliç, D. K. (2010). İşletmelerin Kurumsal Sosyal Sorumluluk Düzeylerinin Belirlenmesine Yönelik Bir Literatür Taraması. Ege Akademik Bakis, 10(1), 303-318. 
Jaggi, B., \& Freedman, M. (1992). An examination of the impact of pollution performance on economic and market performance: Pulp and paper firms. Journal of Business Finance \& Accounting, 19(5), 697-713.

Jones, S., Van der Laan, S., Frost, G., \& Loftus, J. (2008). The investment performance of socially responsible investment funds in Australia. Journal of Business Ethics, 80(2), 181-203.

Kavut, L. (2010). Kurumsal Yönetim, Kurumsal Sosyal Sorumluluk Ve Çevresel Raporlama: İMKB 100 Şirketlerinin Çevresel Açıklamalarının İncelenmesi. Yönetim: İstanbul Üniversitesi İşletme İktisadı Enstitüsü Dergisi, 66, 9-43.

Khan, H. U. Z. (2010). The effect of corporate governance elements on corporate social responsibility (CSR) reporting: Empirical evidence from private commercial banks of Bangladesh. International Journal of Law and Management, 52(2), 82-109.

Makni, R., Francoeur, C., \& Bellavance, F. (2009). Causality between corporate social performance and financial performance: Evidence from Canadian firms. Journal of Business Ethics, 89(3), 409-422.

Muller, A., \& Kolk, A. (2010). Extrinsic and intrinsic drivers of corporate social performance: Evidence from foreign and domestic firms in Mexico. Journal of Management Studies, 47(1), 1-26.

Oh, W. Y., Chang, Y. K., \& Martynov, A. (2011). The effect of ownership structure on corporate social responsibility: Empirical evidence from Korea. Journal of Business Ethics, 104(2), 283-297.

Patten, D. M. (1991). Exposure, legitimacy, and social disclosure. Journal of Accounting and Public Policy, 10(4), $297-308$.

Roberts, R. W. (1992). Determinants of corporate social responsibility disclosure: An application of stakeholder theory. Accounting, Organizations and Society, 17(6), 595-612.

Ruf, B. M., Muralidhar, K., Brown, R. M., Janney, J. J., \& Paul, K. (2001). An empirical investigation of the relationship between change in corporate social performance and financial performance: A stakeholder theory perspective. Journal of Business Ethics, 32(2), 143-156.

Suzuki, K., Tanimoto, K., \& Kokko, A. (2010). Does foreign investment matter? Effects of foreign investment on the institutionalisation of corporate social responsibility by Japanese firms. Asian Business \& Management, 9(3), 379-400.

Trotman, K. T., \& Bradley, G. W. (1981). Associations between social responsibility disclosure and characteristics of companies. Accounting, Organizations and Society, 6(4), 355-362.

US SIF. (2014). Report on US sustainable, responsible and impact investing trends 2014. Washington, DC: The Forum for Sustainable and Responsible Investment.

Vitezic, N. (2011). Corporate reputation and social responsibility: An analysis of large companies in Croatia. The International Business \& Economics Research Journal, 10(8), 85-96.

Waddock, S. A., \& Graves, S. B. (1997). The corporate social performance-financial performance link. Strategic Management Journal, 18(4), 303-319.

Weber, R. P. (1990). Basic content analysis (No. 49). Sage Publications. 


\section{Annex A}

Table A1

CSR Reporting Areas with Subgroups

\begin{tabular}{|l|l|}
\hline CSR reporting area & Subgroup \\
\hline \multirow{4}{*}{ Customers } & Products \\
\cline { 2 - 2 } & Customer satisfaction \\
\cline { 2 - 2 } & Customer education \\
\cline { 2 - 2 } & Other issues related to customers \\
\hline \multirow{5}{*}{ Society } & Employee benefits \\
\cline { 2 - 2 } & Employee structure \\
\cline { 2 - 2 } & Employees' training \\
\cline { 2 - 2 } & Other issues related to employees \\
\hline \multirow{5}{*}{ Ecosystem } & Women \\
\cline { 2 - 2 } & Contribution to SMEs \\
\cline { 2 - 2 } & Contribution to health/education/culture \\
\cline { 2 - 2 } & Other issues related to society \\
\hline Other & Energy \\
\cline { 2 - 2 } & Corporate pollution \\
\cline { 2 - 2 } & Climate change \\
\cline { 2 - 2 } & Other issues related to ecosystem \\
\hline
\end{tabular}

\section{Annex B}

Table B1

CSR Reporting Areas Subgroups with Variables

\begin{tabular}{|c|c|}
\hline Subgroup & Variable \\
\hline \multirow{3}{*}{ Products } & Innovative products \\
\hline & Electronic products \\
\hline & Awards related to products \\
\hline \multirow{3}{*}{ Customer satisfaction } & Improvement of customer complaint systems \\
\hline & Social media/different channel customer satisfaction mechanisms \\
\hline & Product improvements according to customer views \\
\hline \multirow{3}{*}{ Customer education } & Seminars for customer education \\
\hline & Products for customer education \\
\hline & Special products for customer needs \\
\hline \multirow{3}{*}{ Other issues related to customers } & Products for kids \\
\hline & Products for youth \\
\hline & Improvement of product/service quality \\
\hline \multirow{3}{*}{ Employee benefits } & Employee health plan \\
\hline & Employee compensation plan and performance-based bonuses \\
\hline & Career development of employees \\
\hline \multirow{3}{*}{ Employee structure } & Number of employees \\
\hline & Employees categories by title \\
\hline & Employees categories by gender \\
\hline \multirow{3}{*}{ Employees' training } & Number of employees trained \\
\hline & Employees' training cost \\
\hline & Employees' training areas \\
\hline
\end{tabular}


(Table B1 continued)

\begin{tabular}{|c|c|}
\hline Subgroup & Variable \\
\hline \multirow{3}{*}{ Other issues related to employees } & Surveys about employee satisfaction \\
\hline & Improvements on employee communication channels \\
\hline & Events organized for employees \\
\hline \multirow{3}{*}{ Women } & Supporting women entrepreneurs \\
\hline & Support for women in need \\
\hline & Education for women \\
\hline \multirow{3}{*}{ Contribution to SMEs } & Support for agriculture and rural sustainability \\
\hline & Training for SMEs \\
\hline & Provide financial sources from international organizations for SMEs \\
\hline \multirow{3}{*}{ Contribution to health/education/culture } & Donations to schools \\
\hline & Donations to hospitals \\
\hline & Donations to museums/historical sites \\
\hline \multirow{3}{*}{ Other issues related to society } & Handicapped \\
\hline & Sponsorships/donations to different sports organizations and other events \\
\hline & Donations to art events/organizations \\
\hline \multirow{3}{*}{ Energy } & Support for alternative energy projects \\
\hline & Support for renewable energy projects \\
\hline & Provide financial sources from international organizations for energy projects \\
\hline \multirow{3}{*}{ Corporate pollution } & Improvements on reducing environmental impact of the bank \\
\hline & Carbon level and water saving policy of the bank \\
\hline & Improvements in energy saving of the bank \\
\hline \multirow{3}{*}{ Climate change } & Planting trees \\
\hline & Donations to environmental organizations \\
\hline & Support for recycling projects \\
\hline \multirow{3}{*}{ Other issues related to ecosystem } & Selective financing policy for projects which are harmful to environment \\
\hline & Selective financing policy for projects which are harmful to historic sites \\
\hline & Paperless practices \\
\hline \multirow{2}{*}{ Other } & Existence of CSR committee \\
\hline & Signing and improvements in UN Global Compact \\
\hline
\end{tabular}

\section{Annex C}

Table C1

List of Banks in the Sample

\begin{tabular}{|l|l|}
\hline Banks in the sample & \\
\hline \multirow{4}{*}{ State-owned deposit banks } & Türkiye Cumhuriyeti Ziraat Bankası A.Ş. \\
\cline { 2 - 3 } & Türkiye Halk Bankası A.Ş. \\
\cline { 2 - 3 } Privately-owned deposit banks & Türkiye Vakıflar Bankası T.A.O. \\
\hline \multirow{5}{*}{} & Akbank T.A.Ş. \\
\cline { 2 - 2 } & Anadolubank A.Ş. \\
\cline { 2 - 2 } & Fibabanka A.Ş. \\
\cline { 2 - 2 } & Şekerbank T.A.Ş. \\
\hline & Turkish Bank A.Ş. \\
\cline { 2 - 2 } & Türk Ekonomi Bankası A.Ş. \\
\cline { 2 - 2 } & Türkiyeİş Bankası A.Ş. \\
\cline { 2 - 2 } & Yapıve Kredi Bankası A.Ş. \\
\hline
\end{tabular}


(Table $\mathrm{C} 1$ continued)

\begin{tabular}{|l|l|}
\hline Banks in the sample & \\
\hline \multirow{5}{*}{ Foreign banks founded in Turkey } & Alternatifbank A.Ş. \\
\cline { 2 - 2 } & Arap Türk Bankası A.Ş. \\
\cline { 2 - 2 } & Burgan Bank A.Ş. \\
\cline { 2 - 2 } & Citibank A.Ş. \\
\cline { 2 - 2 } & Denizbank A.Ş. \\
\cline { 2 - 2 } & Deutsche Bank A.Ş. \\
\cline { 2 - 2 } & Finansbank A.Ş. \\
\hline & HSBC Bank A.Ş. \\
\hline & ING Bank A.Ş. \\
\hline & Odea Bank A.Ş. \\
\hline & Turkland Bank A.Ş. \\
\hline & Türkiye Garanti Bankası A.Ş. \\
\hline
\end{tabular}

